\title{
Linking surface and subsurface properties of biocrusted and non-biocrusted habitats of fine-grained fluvial sediments (playas) from the Negev Desert
}

\author{
Giora J. Kidron
}

Institute of Earth Sciences, The Hebrew University of Jerusalem, Givat Ram Campus, Jerusalem 91904, Israel. Tel: +972-54-4967-271. Fax: 972-2-566-2581. E-mail: kidron@mail.huji.ac.il

\begin{abstract}
With biocrusts playing a cardinal role in $\mathrm{C}$ and $\mathrm{N}$ fixation in arid zones, information regarding the factors that determine their limits of growth is of uttermost importance for the study of ecosystem structure and function. This is also the case in the western Negev dunefields, where although abundant on the sandy surfaces, biocrusts are scarce on finegrained (mainly loessial) sediments, termed playas. In the Nizzana research site (NRS), visibly distinct surfaces, with and without biocrusts were noted within a single playa. In an attempt to characterize these distinct surfaces, a set of random measurements were carried out, which included measurements of crack density, microrelief and chlorophyll content of the upper 0-1 cm. Following a cluster analysis, four distinct types of surfaces (hereafter habitats) were defined, one with substantial amount of chlorophyll content which can be regarded as biocrust (P4), and three non-crusted surfaces (P1P3). Within each type, two $50 \mathrm{~cm}$-deep pits were dug and the $\mathrm{pH}$, electrical conductivity (EC) and fine (silt and clay) content (FC) of samples collected at 1-5, 5-10, 10-20, 20-30, 30-40 and 40-50 cm-depth were analyzed. In addition, periodical moisture measurements were carried out (in pairs) to a depth of 0-20 cm at each surface type during 2013/14. All non-crusted habitats (P1-P3) were characterized by loessial subsurface sediments. Conversely, P4 was either characterized by loessial subsurface sediments (and in this case it was characterized by a slightly concave surface) or having a sandy subsurface (at $\sim 5-10 \mathrm{~cm}$ depth). While the non-crusted surfaces exhibited low moisture content, P4 exhibited deeper and higher moisture content explained either by the more sandy sediments or by lower water loss through runoff. The findings point to the close link between surface and subsurface properties and indicate that water availability may explain biocrust establishment and growth also at the loessial playa surfaces. Biocrusts may thus serve as bioindicators for habitats with high moisture content.
\end{abstract}

Keywords: Available water content; Loess; Soil moisture.

\section{INTRODUCTION}

Playing a cardinal role in C (Elbert et al., 2012; Lange et al., 1992) and N (Johnson et al., 2007; Mayland and McIntosh, 1966; Strauss et al., 2012) fixation in arid zones, the factors that determine biocrust distribution are of utmost importance. Highbiomass and an absence of biocrusts may imply high and low input of $\mathrm{C}$ and $\mathrm{N}$, respectively (Kidron et al., 2015a, b), affecting in turn ecosystem structure and function (Weltzin et al., 2003; Yang et al., 2011). Of special interest are the factors that control biocrust establishment and determine the 'limit of life' threshold above which their establishment is possible. This is also the case in the western Negev dunefields, where although abundant on the sandy surfaces, biocrusts are scarce on the fine-grained (mainly loessial) sediments, termed playas.

Playas are common in arid ecosystems. Being remnants of previous close-basin lakes during previous wet palaeoclimate (Bowler et al., 1986; Magee et al., 1995) or ephemeral water bodies following occasional inundations (Handford, 1982; Magee et al., 1995), the playas are characterized by low organic matter (Bowler et al., 1986) and low-porosity fine-grained sediments, mainly consisting of silt and clay (Bowler et al., 1986). These flat fine-grained sediments characterized many of the arid and semi-arid regions of the world, reported, among other places, from the arid regions of the southwestern USA (Handford, 1982; Malek, 2003; Wondzell et al., 1990), the Sahara (Hamdi-Aissa et al., 2004; Schild and Wendorf, 2001), Namibia (Ward, 1988), China (Pachur and Wünnemann, 1995; Vengosh et al., 1995) and Australia (Bowler et al., 1986; Magee et al., 1995). In contrast to playa lakes which are wet $>75 \%$ of the year, playas are defined as sediments which are dry $>75 \%$ of the year (Briere, 2000). Being predominantly saline (Magee et al., 1995; Vengosh et al., 1995), they are clearly visible by their pale color and their extremely low cover (or absence) of vegetation. Many of the playas also lack biocrusts and subsequently the protective role provided by the biocrusts turning them into an effective wind-blown source of dust (Lee et al., 2009; Reynolds et al., 2007; Sweeney et al., 2011).

Also common in the arid regions of Israel (Amit et al., 1999; Blume et al., 2008; Pen-Mouratov et al., 2011; Yu et al., 2012), the presence of playas in the Hallamish dunefield in the western Negev Desert (Israel) is of special interest. Whereas biocrusts cover all sandy surfaces of the interdunes, biocrusts do not inhabit most of the playas within the dunefield. In contrast to the aeolian formation of the longitudinal dunes, these playas were deposited by the adjacent Nahal Nizzana (dry river bed, also termed wadi or arroyo) during occasional floods, during which dunes blocked the river bed, forcing flood water to penetrate into the dunefield (Kidron, 2001). Sediments carried by the flood water were deposited in low-topographical loci, usually $40-80 \mathrm{~m}$ in diameter and $1-2 \mathrm{~m}$ deep, creating bright flat and bare patches, which are easily distinguished from the adjacent undulating and relatively dark and sparsely vegetated interdune surfaces (Fig. 1a).

These loessial sediments have a different hydrological regime. In contrast to loose sand that does not produce runoff and is therefore characterized by deep infiltration (Hillel and Tadmor, 1962; Kidron, 1999), these fine-grained playa surfaces do not facilitate deep infiltration while readily generating runoff (Blackburn, 1975; Kidron et al., 2012b; Kidron, 2014a). While runoff may take place in humid regions following water repellency (Cerdá, 1997; Lichner et al., 2007), this is not the case in 

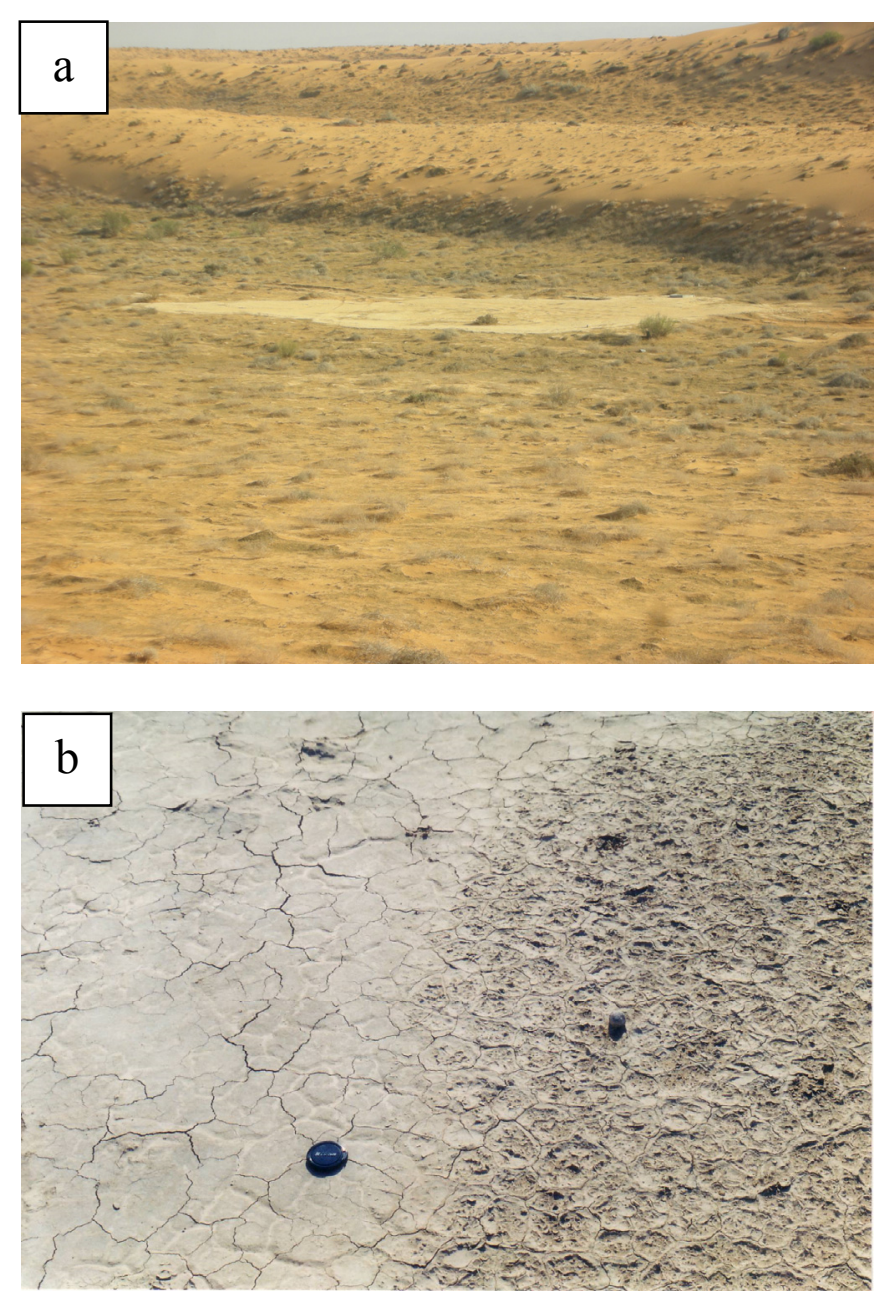

Fig. 1. General view of the playa at the middle of the interdune (a) and a clear boundary between high-microrelief (which characterize the biocrusted surface) at the right side of photograph, and lowmicrorelief surfaces at the left side of photograph (b).

NRS, where runoff is produced following surface pore clogging (Kidron, 2014a).

While most of the playa surfaces in the Hallamish dune field lack biocrusts, biocrusts were noted in certain loci which occupy $\sim 25 \%$ of the playas. These surfaces were easily distinguished, especially by their higher microrelief (Fig. 1b). The aim of the research was to examine the hypothesis that biocrusted surfaces benefit from higher moisture content dictated in turn by the upper soil layers. The research entailed measurements of the variable properties of distinctive visible microhabitats (hereafter habitats) as well as periodic moisture measurements carried out during the rainy season of 2013/14.

\section{THE RESEARCH SITE AND METHODOLOGY}

The research was conducted in the Nizzana research site (NRS) of the Hallamish dunefield in the western Negev Desert, Israel $\left(34^{\circ} 23^{\prime} \mathrm{E}, 30^{\circ} 56^{\prime} \mathrm{N}\right)$. The dunefield, which consists of up to 15-20 m high longitudinal (west-east trending) dunes separated by 50-200 m-wide interdunes, comprises the easternmost terminus of the northern Sinai Peninsula-northwestern Negev erg (Roskin et al., 2011). While long-term mean annual precipitation (1950-1980) is $95 \mathrm{~mm}$ (Rosenan and Gilad, 1985), falling between November and April, it was only $66.5 \mathrm{~mm}$ during 1994-2012 (Kidron, 2015). Mean daily annual temperature is $20^{\circ} \mathrm{C}$; it is $26.5^{\circ} \mathrm{C}$ during the hottest month of July and $11.8^{\circ} \mathrm{C}$ during the coldest month of January. Annual potential evaporation is $\sim 2600 \mathrm{~mm}$ (Evenari, 1981).

For the current research, a $40 \mathrm{~m}$-diameter playa was chosen. The playa has a gentle $3^{\circ}$-slope towards south, reflected in north-south oriented rills that point to the occurrence of runoff at the playa surface, as also previously reported (Kidron, 2014a). This is further supported by the presence of a 3-4 mdiameter depression at the southern edge of the playa, which serves as a sink for runoff (Kidron and Vonshak, 2012).

Three transects with 6 plots each $(\sim 0.8 \mathrm{~m} \mathrm{x} 0.8 \mathrm{~m}$ in intervals of 4-5 m) were demarcated within the playa. The properties of each plot were monitored. Measurements included crack density, microrelief, $\mathrm{pH}$, electrical conductivity (EC), chlorophyll content and the fine (silt and clay) content. Following cluster analysis during which four types of surfaces (habitats) were identified (P1-P4), a pair of pits were dug in each habitat to a depth of $50 \mathrm{~cm}$ and the $\mathrm{pH}$, electrical conductivity (EC) and fine (silt and clay) content (FC) was determined at 1-5, 5-10, $10-20,20-30,30-40$, and 40-50 cm-depth. In addition, periodically moisture measurements were conducted at $1-5,5-10$, $10-15$, and $10-20 \mathrm{~cm}$ in a pair of sites of each type of habitats during the growing seasons of 2013/14.

For the identification of surface properties, crack density, microrelief and chlorophyll content were measured. Crack density was determined by measuring the length of cracks in each plot ( 3 repetitions for each) within $10 \times 10 \mathrm{~cm}$ frame. The microrelief was measured with $18.8 \mathrm{~cm}$ long profilemeter (with 60 rods spaced at $3.1 \mathrm{~mm}$ apart). The variance in rod height (in absolute values) represented roughness (Kidron, 2007; Sanchez and Wood, 1987). Calculation of the average variance in rod height (in millimeter) per $1 \mathrm{~cm}$ length was carried out with the assistance of photographs taken for each measurement (3 replicas for each plot). Chlorophyll $a$ (hereafter chlorophyll) was determined in $1.0 \mathrm{~cm}$ thick of $1.2 \mathrm{~cm}$ diameter cores, taken from each plot ( 3 replicates for each plot). The samples were extracted by hot methanol $\left(70^{\circ} \mathrm{C}, 20 \mathrm{~min}\right)$ in the presence of $\mathrm{MgCO}_{3}(0.1 \% \mathrm{w} / \mathrm{v})$ in sealed test tubes and assayed according to Wetzel and Westlake (1969).

For the determination of the $0-10 \mathrm{~cm}$ upper surface, $\mathrm{pH}, \mathrm{EC}$ and FC were measured. $\mathrm{pH}$ and $\mathrm{EC}$ ( 2 replicas for each plot) were measured in a saturated paste with MP-103, and Exstick EC400 (Extech Instruments, Taiwan), respectively. As for FC, it was measured in $\sim 20 \mathrm{~g}$ samples. The samples were mixed with $0.5 \%$ of sodium hexametaphosphate and treated by ultrasonic waves for $10 \mathrm{~min}$ to ensure silt and clay separation. They were then wet sieved through a 63 micron mesh and the percent of the silt and clay $(<63 \mu)$ within the sample was calculated.

Rain was measured in a nearby meteorological station, $4.5 \mathrm{~km}$ south of the research site, and with a small rain gauge at the playa, that measured the in-situ (i.e., hydrological) rain. The hydrological rain served to adjust the quantities measured in the meteorological station, which at times exhibited differences (usually small) due to variable rain intensities. For the determination of the available water content (AWC), measurements of the gravimetric water content were manually conducted in 20$30 \mathrm{~g}$ samples. Although time-consuming, direct measurements by weight provide the most exact values of the amount of water within the soil sample, serving therefore as the standard calibration method for all other methods, such as moisture sensors connected to data loggers (Yoder et al., 1998) or neutron gauges (Leib et al., 2003), which are used in turn for the calibration of moisture obtained using remote sensing methods (Famiglietti et al., 1999). It is worth mentioning, that water loss following soil disturbance and the manual sampling is negligible due to 
the fact that sampling is carried out within minutes after digging and due to low evaporation rates during the rainy season (of $<2 \mathrm{~mm} \mathrm{~d}^{-1}$; see Kidron, 2009).

In order to account for the difference in texture, the volumetric water content was then calculated based on the average bulk density as determined by pressure plates (Kidron et al., 2002). The volumetric water content was first calculated in accordance with the equation:

$W v=W w^{*} D b / D w$

Where $W v\left(\mathrm{~cm}^{3} \mathrm{~cm}^{-3}\right)$ is the volumetric water content, $W w(\mathrm{~g})$ the gravimetric water content, $D b\left(\mathrm{~g} \mathrm{~cm}^{-3}\right)$ is the soil bulk density and $D w\left(\mathrm{~g} \mathrm{~cm}^{-3}\right)$ is the water density $(\approx 1)$.

Thereafter, AWC was determined in accordance with Hillel and Tadmor (1962):

$A W C=W v-W w p$

Where $A W C$ is the available water content $\left(\mathrm{cm}^{3} \mathrm{~cm}^{-3}\right)$ and $W w p$ $\left(\mathrm{cm}^{3} \mathrm{~cm}^{-3}\right)$ is the amount of the volumetric water at wilting point.

For the establishment of the differences between the habitats, one-way ANOVA was executed (SPSS version 11; IL, Chicago, USA). Once exhibiting significant differences, the Tukey post-hoc test was used to identify differences between habitats. Data were regarded significant at $P<0.05$.

\section{RESULTS AND DISCUSSION}

When characterized by the crack density, microrelief, and chlorophyll content of the surface and by the $0-10 \mathrm{~cm}$ deep $\mathrm{pH}$ and EC, cluster analysis shows four distinct types of surfaces (P1-P4). When the upper $0-10 \mathrm{~cm}$ FC was included, P4 was subdivided to P4l (with 1 denoting a loessial subsurface) and
P4s (with s denoting a sandy subsurface) (Fig. 2). Considering the focus of the current research, the findings therefore point to the presence of one biocrusted ( $\mathrm{P} 4)$ and three non-biocrusted (P1-P3) habitats.

The four distinct habitats exhibited a gradual increase in crack density and roughness from P1 to P4 (Fig. 3a, b). A gradual increase also characterized the chlorophyll content (Fig. 3c). Lower pH (Fig. 3d) but very high EC (Fig. 3e) characterized P1 in comparison to $\mathrm{P} 2, \mathrm{P} 3$ and $\mathrm{P} 4$, with $\mathrm{EC}$ values showing a decreasing conductivity with $\mathrm{P} 1(8.4 \mathrm{mS})>\mathrm{P} 2(1.67 \mathrm{mS})>\mathrm{P} 3$ $(1.22 \mathrm{mS})>\mathrm{P} 4(1.00 \mathrm{mS})$. As for $\mathrm{FC}$, non-significant differences characterized the $\mathrm{P} 1-\mathrm{P} 3$ habitats (with $\mathrm{FC}>80 \%$, although exhibiting a general decrease from P1 to P3) with P4 exhibiting a significant decrease. With two out of the five plots in P4 exhibiting low fine content of $45-60 \%$ (with an average of $52.7 \%$ for $\mathrm{P} 4 \mathrm{~s}$ as opposed to $81.9 \%$ for $\mathrm{P} 41$ ), the combined average dropped substantially to $68.1 \%$ at the $0-10 \mathrm{~cm}$, being also characterized by a high standard error (Fig. 3f).

The four habitats showed a distinct appearance, mainly due to the differences in crack density and microrelief (Fig. 4). Whereas $\mathrm{P} 1$ and $\mathrm{P} 4$ covered $\sim 40-50 \%$ and $\sim 20-25 \%$ of the playa surface, respectively, P3 and P4 occupied each $\sim 15-20 \%$ of the playa. Apart from crack density and microrelief, the differences were also reflected in the chlorophyll content. Only P4 exhibited a visibly greening effect (sensu Brock, 1975) as previously noted in NRS (Kidron et al., 2012a) upon extended wetness during a cloudy day, and therefore could be regarded as biocrusted. Indeed, these biocrusts were predominantly inhabited by the filamentous Microcoleus vaginatus, as verified during microscopic examinations, carried out by Burkhard Büdel (University of Kaiserlautern, Germany). Microcoleus sp., which is regarded as a pioneer biocrust species (Büdel, 2005), is indeed known for its high motility, triggered by a search for optimum light (Campbell, 1979) and water (Garcia-Pichel and Pringault, 2001).

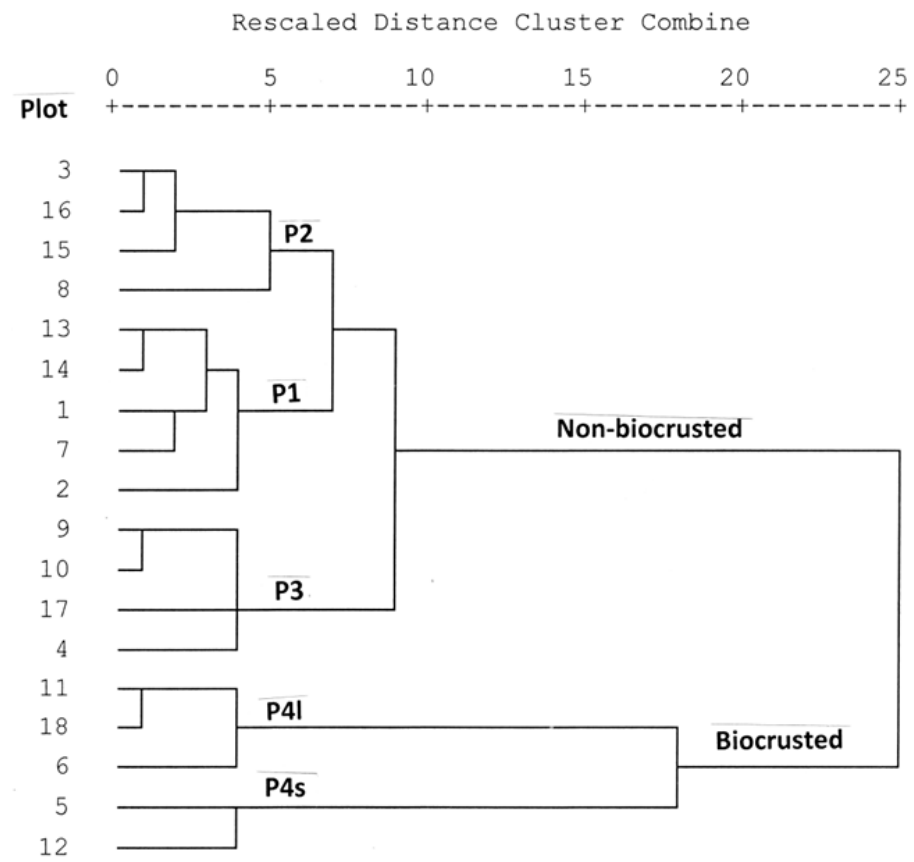

Fig. 2. Cluster analysis showing four principal types of habitats P1 (a), P2 (b), P3 (c) and P4 (d). While the habitats P1-P3 are non-biocrusted, $\mathrm{P} 4$ is a biocrusted habitat. $\mathrm{P} 41$ and $\mathrm{P} 4 \mathrm{~s}$ denote a loessial and sandy $5-10 \mathrm{~cm}$ subsurface, respectively. 

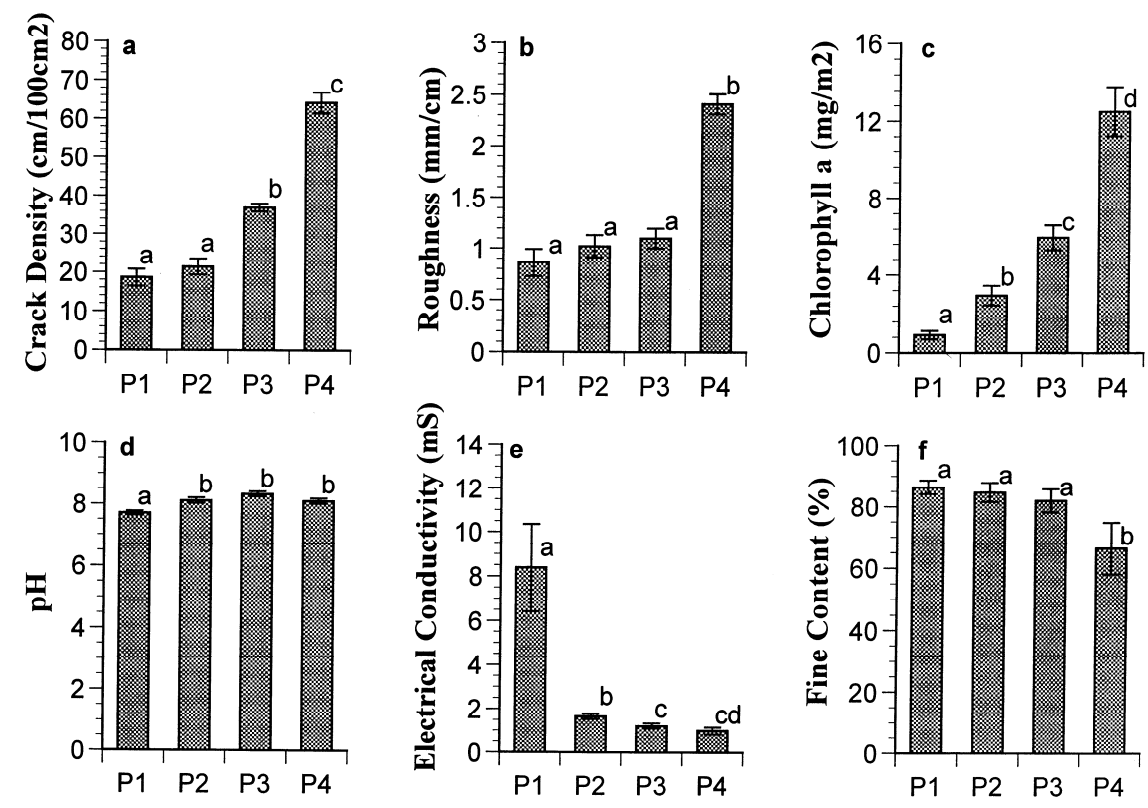

Habitat

Fig. 3.Average surface values of crack length (a), microrelief (b) and chlorophyll $a$ content (c), and average values for the upper $0-10 \mathrm{~cm}$ of $\mathrm{pH}(\mathrm{d})$, electrical conductivity, EC (e) and fine content, FC (f). Bars represent one SE. Different letters indicate significant differences $(P<0.05)$.
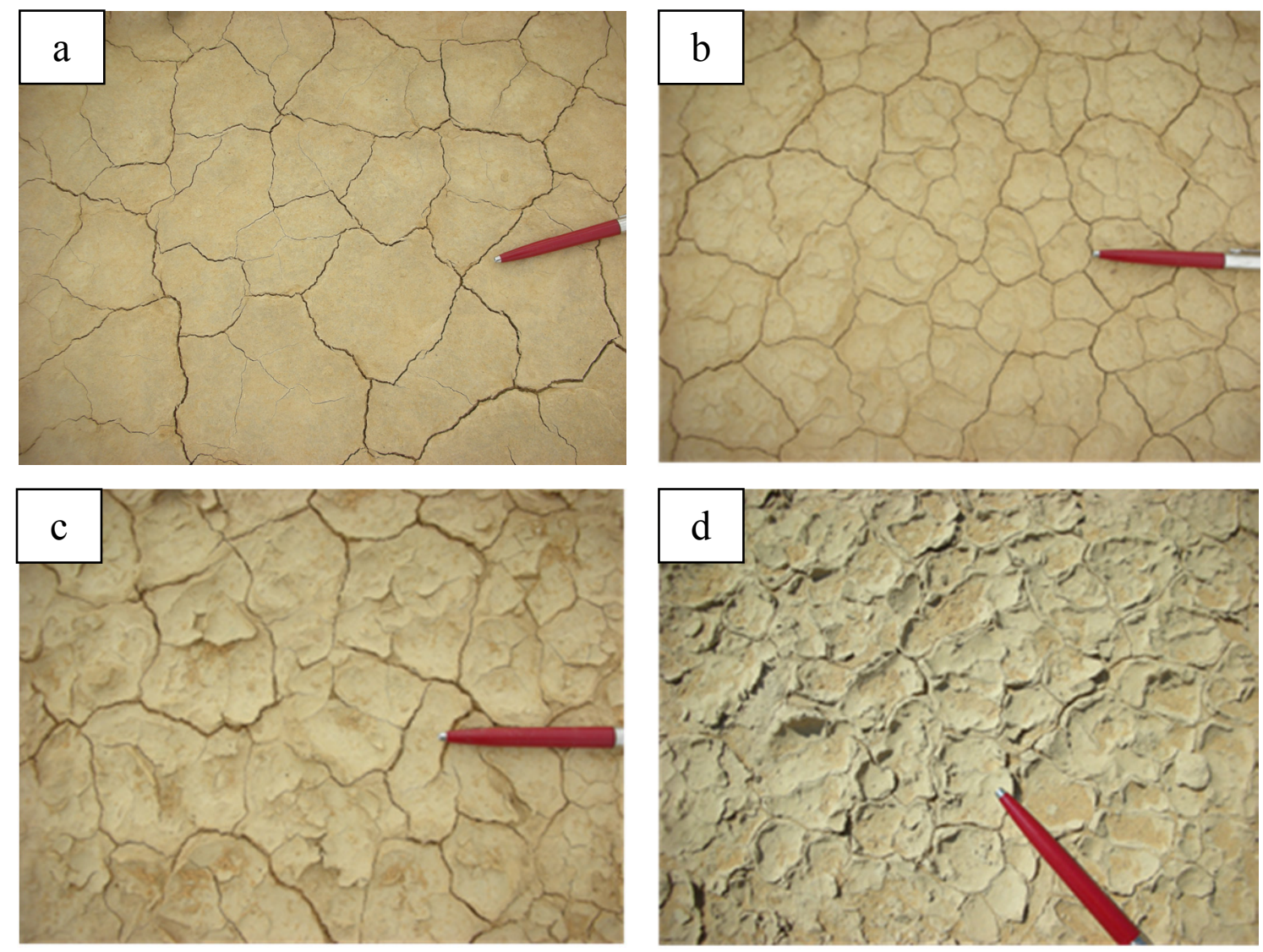

Fig. 4. Close view of the habitat P1 (a), P2 (b), P3 (c), and P4 (d). 
In comparison to chlorophyll values of $<6 \mathrm{mg} \mathrm{m}^{2}$ of habitats $\mathrm{P} 1-\mathrm{P} 3$, the cyanobacterial crust of $\mathrm{P} 4$ was characterized by an average chlorophyll content of $12.5 \mathrm{mg} \mathrm{m}^{2}$. Regardless whether at $\mathrm{P} 41$ or $\mathrm{P} 4 \mathrm{~s}$, chlorophyll content ranged between $8-17 \mathrm{mg} \mathrm{m}^{-2}$ at both subplots. Taking the greening effect as an easy visible indicator for biocrusts, one can conclude that chlorophyll content of $\sim 10 \mathrm{mg} \mathrm{m}^{2}$ may be regarded as a rough threshold for biocrusts, and consequently, $\mathrm{P} 4$ can be regarded as biocrusted. One should however be aware of the fact that some $M$. vaginatus filaments could have been observed at P3. However, they were of very low density and did not exhibit a visible 'greening effect'.

In this regard it is interesting to note that while sandy surfaces with a chlorophyll content of $<10 \mathrm{mg} \mathrm{m}^{2}$ did not yield runoff, surfaces with a chlorophyll content of $>10 \mathrm{mg} \mathrm{m}^{-2}$ readily yielded runoff as early as two years after scalping (Kidron, 2007). Runoff generation from these surfaces was attributed to a juvenile biocrust, sufficiently dense to generate runoff. Similarly, the 'greening effect' at P4 points to sufficiently dense filaments, supporting the conclusions that surfaces with a chlorophyll content of $\geq 10 \mathrm{mg} \mathrm{m}^{2}$ can be regarded as biocrusts.

When the $\mathrm{pH}, \mathrm{EC}$, and $\mathrm{FC}$ of the soil profiles of each of the four habitats were examined (Fig. 5), some points emerge:

(a) All samples, regardless of surface type, exhibited a general increase in the $\mathrm{pH}$ from $0-1 \mathrm{~cm}$ to $1-5 \mathrm{~cm}$ and a decrease thereafter. All values were $\geq 7.42$.

(b) Initially, EC exhibited increasingly higher values with depth, with maximum values at $20-30 \mathrm{~cm}$. P4 exhibited the lower EC values at $5-10 \mathrm{~cm}$. (c) While almost all samples have high FC, this is not the case for two of the P4 samples, which showed an average FC of only $23.2 \%$ at $5-10 \mathrm{~cm}$.

(d) Similar properties characterized the subsurface horizons, especially below $10 \mathrm{~cm}$.

The high maximum EC at 20-30 cm may indicate maximal water infiltration and hence terminal salt deposition at these depths. This is in agreement with the high responsiveness of the playa surfaces to rain. Following low rates of infiltration (Blackburn, 1975), excess of water runs off the compacted playa surfaces resulting in high runoff yield (Kidron, 2014a). While most of the runoff will leave the playa, slightly concave surfaces will not readily produce runoff, allowing for most of the rain to infiltrate at these loci, as noted for P4l. Alternatively, some of the $\mathrm{P} 4$ plots $(\mathrm{P} 4 \mathrm{~s})$ were characterized by a large-pore sandy layer at 5-10 $\mathrm{cm}$ depth, which may be seen as a local "water reservoir".

The reason for the sandy layer at $5-10 \mathrm{~cm}$ is unclear. One possible scenario is that the sandy layer may have resulted from animal digging, such as by gazelle (as often observed in the field). These digs may have been subsequently filled with windblown sand, and later covered by local runoff-laden finetextured sediments. The clear and non-fragmented gradients in EC and especially FC with depth do not support multiple inundation events. Although reported from other playas adjacent $(\sim 0.5 \mathrm{~km})$ to Nahal Nizzana (Blume et al., 2008), the current findings point to the great similarity at the deeper soil layers $(>10 \mathrm{~cm})$, as verified by the $\mathrm{pH}, \mathrm{EC}$ and $\mathrm{FC}$, supporting the notion that the upper $50 \mathrm{~cm}$ of the current playa was apparently
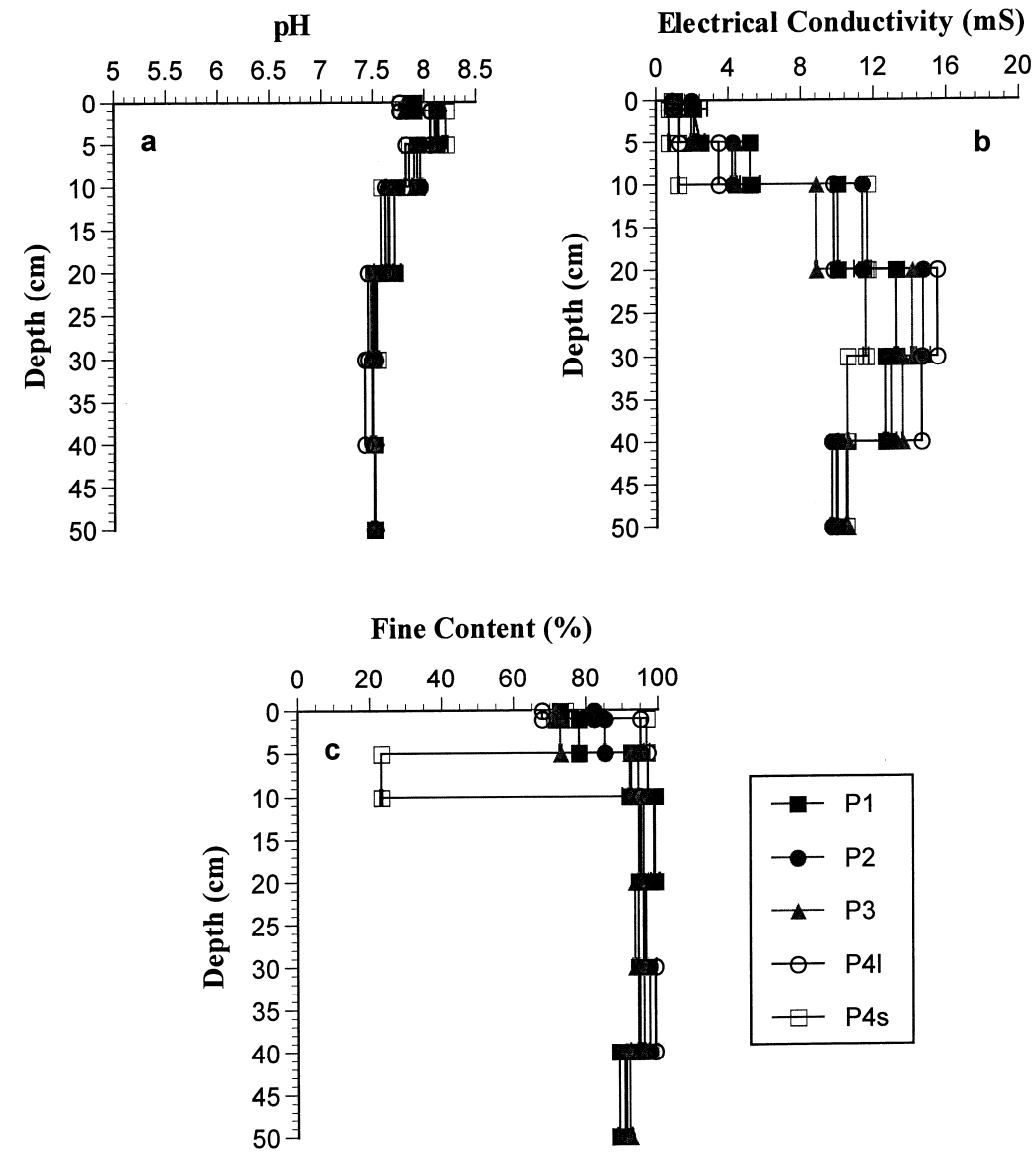

Fig. 5. The distribution of $\mathrm{pH}(\mathrm{a})$, electrical conductivity, EC (b) and fine content, FC (c) at $0-50 \mathrm{~cm}$ of the four habitats (P1-P4). Denote the lower FC at 5-10 cm of P4s. Bars represent one SE. 
deposited during a single event - a likely scenario due to the great distance of the playa $(\sim 2 \mathrm{~km})$ from Nahal Nizzana. While having similar properties at depth $(30-50 \mathrm{~cm})$, P4 exhibited different properties at $5-10 \mathrm{~cm}$. Nevertheless, whether characterized by an entirely loessial profile or a sandy subsurface at $5-10 \mathrm{~cm}, \mathrm{P} 4$ retained its moisture longer following rain, as verified during the rainy season of 2013/14.

The rainy season of $2013 / 14$ was wet, with a total of $125.8 \mathrm{~mm}$. It was characterized by three $>20 \mathrm{~mm}$ and three $>10$ $\mathrm{mm}$ rainstorms (Fig. 6). When the moisture content of $\mathrm{P} 1, \mathrm{P} 41$ and $\mathrm{P} 4 \mathrm{~s}$, was periodically monitored, substantial higher AWC characterized P4 (both $\mathrm{P} 41$ and $\mathrm{P} 4 \mathrm{~s}$ ) in comparison to P1. The AWC at P2 and P3 was also slightly higher than that of P1, as verified during periodical measurements (not shown). This is explained by the lower FC at the $0-10 \mathrm{~cm}$ at $\mathrm{P} 2$ and $\mathrm{P} 3$ in comparison to $\mathrm{P} 1$, which apparently allows for slightly higher infiltration (and therefore higher AWC), reflected in turn in the lower EC values of $\mathrm{P} 2$ and $\mathrm{P} 3$ at $0-10 \mathrm{~cm}$ in comparison to $\mathrm{P} 1$ (Fig. 3e).

While biocrusts may affect the AWC following their higher capacity to absorb water (Kidron, 2014b), the overall effect of biocrusts on the entire soil profile due to their higher waterholding capacity (WHC) is very small and may be regarded as negligible. This stems from the fact that the biocrusts are confined to a very thin $(0.3-0.4 \mathrm{~cm})$ layer, many folds thinner than the wetted profile. Additionally, by inhabiting the upper surface which is subjected to intense and therefore rapid evaporation, the positive effect of the crusts due to their high WHC may only be short-lasting, as previously reported (Kidron, 2014b).

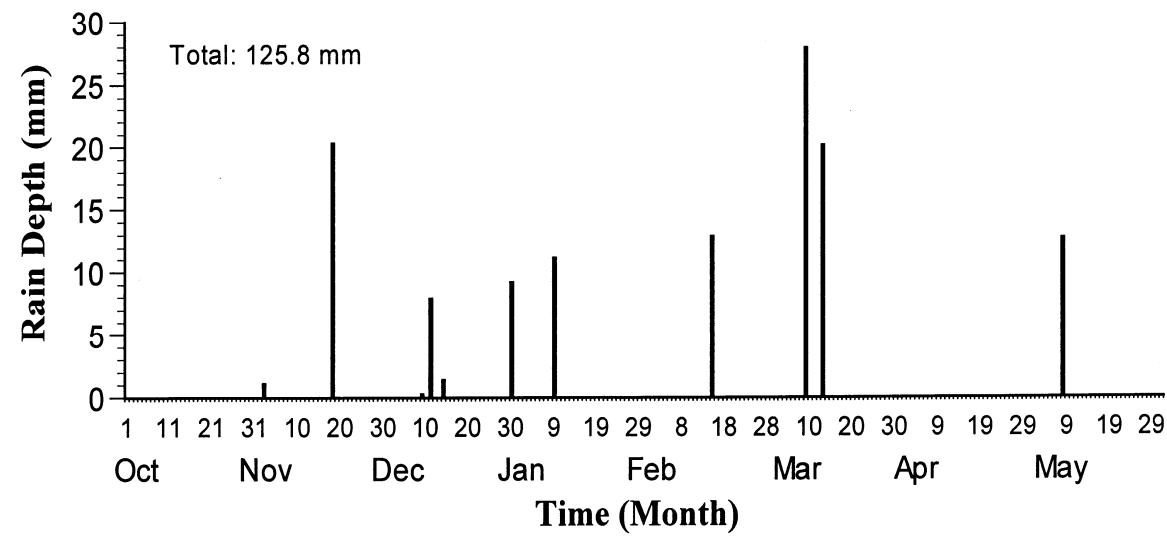

Fig. 6. Rainstorm distribution during 2013/2014.

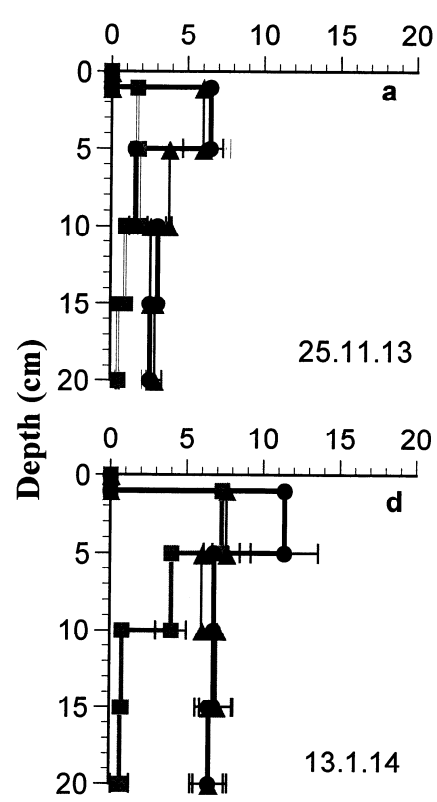

Soil Moisture (\%)
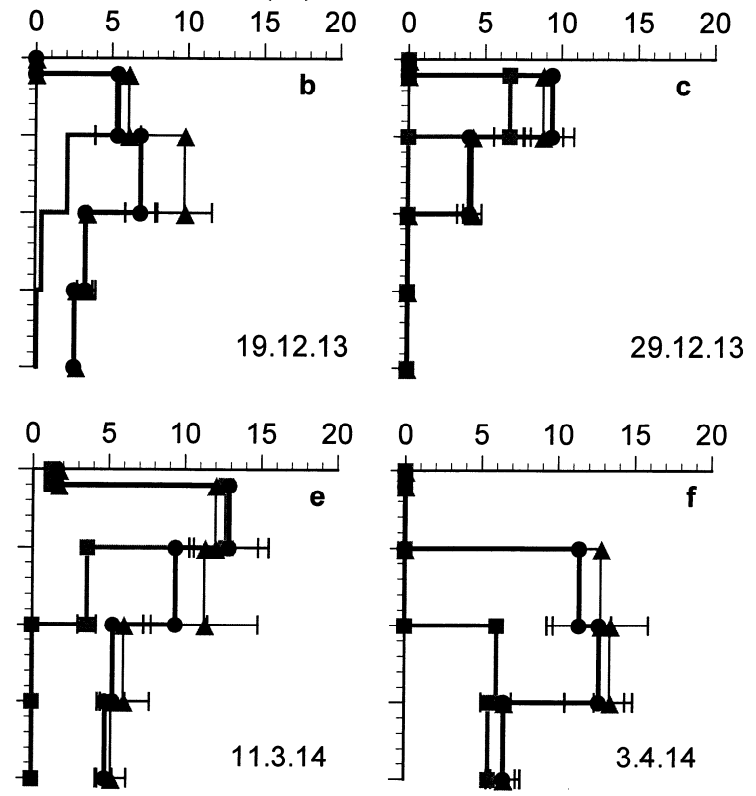

$\rightarrow \mathrm{P} 1 \rightarrow \mathrm{P} 4 \mathrm{I} \rightarrow \mathrm{P} 4 \mathrm{~s}$

Fig. 7. Periodic measurement of the available water content (AWC) at $0-20 \mathrm{~cm}$ of $\mathrm{P} 1, \mathrm{P} 4_{1}$ and $\mathrm{P} 4_{\mathrm{s}}$. Note the substantial lower $\mathrm{AWC}$ at $\mathrm{P} 1$. Bars represent one SE. 
The significantly higher AWC at P4 can be clearly noted in Figure 7. This was also verified by a paired t-test. Whereas no significant differences were found in the AWC of $\mathrm{P} 41$ and $\mathrm{P} 4 \mathrm{~s}$ $(P=0.67)$, significantly higher amounts characterized $\mathrm{P} 4$ in comparison to $\mathrm{P} 1(P=0.003)$. As can be seen in Figure $7, \mathrm{P} 4$ also retained its moisture for longer duration, for instance, during 29.12.2013, and 3.4.2014. Moisture recorded at these dates reflected the preceding rain that fell 15 and 20 days earlier, respectively. Due to the fact that these flat surfaces receive similar incoming radiation, the lower rate of evaporation at $\mathrm{P} 4$ may therefore reflect the higher initial moisture content at P4, in agreement with the close link between moisture content and duration that characterize sandy habitats (Kidron, 2010). This higher initial moisture content results from the higher infiltration in P4. This implies in turn more efficient salt leaching and subsequently a decrease in EC. Nevertheless, substantially lower EC was recorded only for the upper $5-10 \mathrm{~cm}$, attesting to the overall limited infiltration depth of the playa surfaces.

Following the close link between subsurface and surface moisture content on sand and between the chlorophyll content of the biocrusts and the surface moisture content of sand (Kidron and Benenson, 2014), one can safely conclude that similar relations also characterize the playa surfaces. Contrary to P1 (and also to P2 and P3 although to lesser degree), P4 exhibited visibly prolonged moisture content following rain events. Also, the slightly higher moisture content found during periodical measurements at P3 in comparison to $\mathrm{P} 1$ is in agreement with the slightly higher chlorophyll values that characterize P3 in comparison to P1. This was also apparent in microscopic observations, during which some $M$. vaginatus filaments could have been observed at P3.

The substantially longer moisture duration at $\mathrm{P} 4$ was verified in numerous field observations. However, contrary to other publications which reported occasional water ponding (Bowler et al., 1986; Briere, 2000), the extremely low and hardly noted concavity at $\mathrm{P} 41$ did not result in clear water ponding. This may explain the absence of roll-up structures that follow ponding, as noted for instance in some restricted loci of the NRS interdunes (see Figure 1c in Kidron, 2014a) and in some playas in southwestern US (Beraldi-Campesi and Garcia-Pichel, 2011). And thus, while most of the incident rain remained in P4, substantial water loss through runoff characterized the non-biocrusted habitats (P1-P3).

This may explain in turn the limited infiltration depth and the relatively high xerosis of the playa surfaces. This was also supported during an analysis of the microfungal population with depth $(0-70 \mathrm{~cm})$. While the amount of CFU (colony forming units which denotes the microfungal density) on sand remained relatively constant with depth (attesting to efficient and deep water infiltration), a substantial decrease characterized the playa surfaces at $>10-20 \mathrm{~cm}$. Additionally, the biocrusted habitat (P4) also exhibited substantially higher CFU in comparison to the non-biocrusted habitats, further attesting to the higher moisture content of the biocrusted habitat (Grishkan and Kidron, 2015).

With maximum chlorophyll content (at P4) being about half that of the adjacent sandy biocrusted interdunes (Kidron and Vonshak, 2012), one may conclude that wetness duration is substantially shorter at the playa surfaces. The findings indicate that lack of sufficient water rather than toxic elements (Blume et al., 1995) may explain biocrust scarcity at the playa surfaces at NRS, as also verified during growth experiments during which cyanobacterial crusts were grown successfully under lab conditions following surface wetting (Kidron, unpub.). The data thus imply that a shortage of water limits the establishment of biocrusts over most of the playa surface.

The findings support the initial hypothesis that differences in the habitat's moisture regime may explain the presence/absence of biocrusts, and that these relations are specifically controlled by the upper $0-10 \mathrm{~cm}$. As reported from sandy surfaces in the Negev (Kidron and Vonshak, 2012) and central Europe (Fischer et al., 2014), and from loessial surfaces in the Chihuahuan Desert (Kidron and Gutschick, 2013), biocrusts at the playa surfaces at NRS point to the possible addition of water. And thus, similarly to sandy surfaces (Kidron et al., 2009), biocrusts at the playa surfaces may serve as bioindicators for habitats with high moisture content. Conversely, surfaces without biocrusts may point to insufficient moisture content. Shortage of moisture will impede biocrust establishment and will subsequently negatively affect the input of $\mathrm{C}$ and $\mathrm{N}$ into the ecosystem.

Acknowledgements. I would like to deeply thank Burkhard Büdel for the identification of the cyanobacteria at the playa surface and Carol A. Kidron for the editing.

\section{REFERENCES}

Amit, R., Zilberman, E., Porat, N., 1999. Relief inversion in the Avrona playa as evidence of large-magnitude historical earthquakes, southern Arava Valley, Dead Sea Rift. Quaternary Res., 52, 76-91.

Beraldi-Campesi, H., Garcia-Pichel, F., 2011. The biogenicity of modern terrestrial roll-up structures and its significance for ancient life on land. Geobiology, 9, 10-23.

Blackburn, W.H., 1975. Factors influencing infiltration and sediment production of semiarid range lands in Nevada. Water Resour. Res., 11, 929-937.

Blume, H.P., Yair, A., Yaalon, D.H., Berkowicz, S.M., 1995. An initial study of pedogenic features along a transect across longitudinal dunes and interdune areas Nizzana region, Negev, Israel. Adv. Geoecol., 29, 51-64.

Blume, H.P., Beyer, L., Pfisterer, U., Felix-Henningsen, P., 2008. Soil characteristics and pattern of the Nizzana research site. In: Breckle, S.W., Yair, A., Veste, M. (Eds.): Arid Dune Ecosystems: The Nizzana sands in the Negev Desert. Springer-Verlag, Berlin Heidelberg, pp. 65-77.

Bowler, J.M., Huang, Q., Chen, K., Head, M.J., Yuan, B., 1986. Radiocarbon dating of playa-lake hydrologic changes: Examples from northwestern China and central Australia. Palaeogeog, Palaeoclim, Palaeoecol., 54, 241-260.

Briere, P.R., 2000. Playa, playa lake, sabkha: Proposed definitions for old terms. J. Arid Environ., 45, 1-45.

Brock, T.D., 1975. Effect of water potential on a Microcoleous (Cyanophyceae) from a desert crust. J. Phycol., 11, 316-320.

Büdel, B., 2005. Microorganisms of biological crusts on soil surfaces. In: Buscot, F., Varma, A. (Eds.): Microorganisms in Soils: Roles in the Genesis and Functions. Springer Verlag, Berlin Heidelberg, pp. 307-321.

Campbell, S.E., 1979. Soil stabilization by prokaryotic desert crusts: implications for Precambrian land biota. Orig. Life, 9, 335-348.

Cerdá, A., 1997. Soil erosion after land abandonment in a semiarid environment of southeastern Spain. Arid Soil Res. Rehab., 11, 168-176.

Elbert, W., Weber, B., Burrows, S., Steinkamp, J., Büdel, B., Andrea, M.O., Pöschl, U., 2012. Contribution of cryptogam- 
ic covers to the global cycles of carbon and nitrogen. Nature Geosci., 5, 459-462.

Evenari, M., 1981. Ecology of the Negev Desert, a critical review of our knowledge. In: Shuval, H. (Ed.): Developments in Arid Zone Ecology and Environmental Quality. Balaban ISS, Philadelphia, Pa, pp. 1-33.

Famiglietti, J.S., Devereaux, J.A., Laymon, C.A., Tsegaye, T., Houser, P.R., Jackson, T.J., Graham, S.T., Rodell, M., van Oevelen, P.J., 1999. Ground-based investigation of soil moisture variability within remote sensing footprints during the Southern Great Plains 1997 (SGP97) Hydrology Experiment. Water Resour. Res., 35, 1839-1851.

Fischer, T., Gypser, S., Subotina, M., Veste, M., 2014. Synergic hydraulic and nutritional feedback mechanisms control surface patchiness of biological soil crusts on tertiary sands at a post-mining site. J. Hydrol. Hydromech., 62, 293302.

Garcia-Pichel, F., Pringault, O., 2001. Cyanobacteria track water in desert soils. Nature, 413, 380-381.

Grishkan, I., Kidron, G.J., 2015. Vertical divergence of microfungal communities through the depth in different soil formations at Nahal Nizzana, western Negev Desert, Israel. Geomicrobiol. J., doi. 10.1080/01490451.2015.1062063.

Hamdi-Aissa, B., Valles, V., Aventurier, A., Ribolzi, O., 2004. Soils and brine geochemistry and mineralogy of hyperarid desert playa, Ouargla Basin, Algerian Sahara. Arid Land Res. Manage., 18, 103-126.

Handford, C.R., 1982. Sedimentology and evaporate genesis in a Holocene continental-sabkha playa basin - Bristol Dry Lake, California. Sedimentology, 29, 239-253.

Hillel, D., Tadmor, N., 1962. Water regime and vegetation in central Negev Highlands of Israel. Ecology, 43, 33-41.

Johnson, S.H., Neuer, S., Garcia-Pichel, F., 2007. Export of nitrogenous compounds due to incomplete cycling within biological soil crusts of arid lands. Environ. Microbiol., 9, 680-689.

Kidron, G.J., 1999. Differential water distribution over dune slopes as affected by slope position and microbiotic crust, Negev Desert, Israel. Hydrol. Process., 13, 1665-1682.

Kidron, G.J., 2001. Runoff-induced sediment yield from dune slopes in the Negev Desert, 2: Texture, carbonate and organic matter. Earth Surf. Process. Landf., 26, 583-599.

Kidron, G.J., 2007. Millimeter-scale microrelief affecting runoff yield over microbiotic crust in the Negev Desert. Catena, 70, 266-273.

Kidron, G.J., 2009. The effect of shrub canopy upon surface temperatures and evaporation in the Negev Desert. Earth Surf. Process. Landf., 34, 123-132.

Kidron, G.J., 2010. Under-canopy microclimate within sand dunes in the Negev Desert. J. Hydrol., 392, 201-210.

Kidron, G.J., 2014a. Sink plot for runoff measurements on semi-flat terrains: Preliminary data and their potential hydrological and ecological implications. J. Hydrol. Hydromech., 62, 303-308.

Kidron, G.J., 2014b. Do mosses serve as sink for rain in the Negev Desert? A theoretical and experimental Approach. Catena, 121, 31-39.

Kidron, G.J., 2015. Dune crests serve as preferential habitats for perennial plants during frequent drought years. J. Hydrol., 522, 295-304.

Kidron, G.J., Benenson, I., 2014. Biocrusts serve as biomarkers for the upper $30 \mathrm{~cm}$ soil water content. J. Hydrol., 509, 398405 .
Kidron, G.J., Gutschick, V., 2013. Soil moisture correlates with shrub-grass association in the Chihuahuan Desert. Catena, 107, 71-79.

Kidron, G.J., Vonshak, A., 2012. The use of microbiotic crusts as biomarkers for ponding, subsurface flow and soil moisture content and duration. Geoderma, 181-182, 56-64.

Kidron, G.J., Vonshak, A., Abeliovich, A., 2009. Microbiotic crusts as biomarkers for surface stability and wetness duration in the Negev Desert. Earth Surf. Process. Landf., 34, 1594-1604.

Kidron, G.J., Barinova, S., Vonshak, A., 2012a. The effects of heavy winter rains and rare summer rains on biological soil crusts in the Negev Desert. Catena, 95, 6-11.

Kidron, G.J., Jones, T.L., Monger, H.C., Starinsky, A., 2002. Factors controlling microbiotic crusts: Negev and the Chihuahuan Desert. Semi Annual Report presented for IALC. May 2002.

Kidron, G.J., Monger, H.C., Vonshak, A., Conrod, W., 2012 b. Contrasting effects of microbiotic crusts on runoff in desert surfaces. Geomorphology, 139-140, 484-494.

Kidron, G.J., Li, X.R., Jia, R.L., Gao, Y.H., Zhang, P., 2015 a. Assessment of carbon gains from biocrusts inhabiting a dunefield in the Negev Desert. Geoderma, 253-254, 102110.

Kidron, G.J., Posmanik, R., Brunner, T., Nejidat, A.,2015b. Spatial abundance of microbial nitrogen-transforming genes and inorganic nitrogen in biocrusts along a transect of an arid sand dune in the Negev Desert. Soil Biol. Biochem., 83, $150-159$.

Lange, O.L., Kidron, G.J., Büdel, B., Meyer, A., Kilian, E., Abeliovitch, A., 1992. Taxonomic composition and photosynthetic characteristics of the biological soil crusts covering sand dunes in the Western Negev Desert. Funct. Ecol., 6, 519-527.

Lee, J.A., Gill, T.E., Mulligan, K.R., Dominguez Acosta, M., Perez, A.E., 2009. Land use/land cover and point sources of the 15 December 2003 dust storm in southwestern North America. Geomorphology, 105, 18-27.

Leib, B.G., Jabro, J.D., Matthews, G.R., 2003. Field evaluation and performance comparison of soil moisture sensors. Soil Sci., 168, 396-408.

Lichner, L., Orfánus, T., Nováková, K., Šír, M., Tesar̆, M., 2007. The impact of vegetation on hydraulic conductivity of sandy soil. Soil Water Res., 2, 59-66.

Magee, J.W., Bowler, J.M., Miller, G.H., Williams, D.L.G., 1995. Stratigraphy, sedimentology, chronology and palaeohydrology of Quaternary lacustrine deposits at Madigan Gulf, Lake Eyre, South Australia. Palaeogeog. Palaeoclim. Palaeoecol., 113, 3-42.

Malek, E., 2003. Microclimate of a desert playa: evaluation of annual radiation, energy, and water budget components. Int. J. Climatol., 23, 333-345.

Mayland, H.F., McIntosh, T.H., 1966. Availability of biologically fixed nitrogen-15 to higher plants. Nature, 209, 421-422.

Pachur, H.J., Wünnemann, B., 1995. Lake evolution in the Tengger Desert, northwestern China, during the last 40,000 years. Quarter. Res., 44, 171-180.

Pen-Mouratov, S., Hu, C., Hindin, E., Steinberger, Y., 2011. Soil microbial activity and a free-living nematode community in the playa and in the sandy biological crust of the Negev Desert. Biol. Fertil. Soils, 47, 363-375.

Reynolds, R.L., Yount, J.C., Reheis, M., Goldstein, H., Chavez, Jr P., Fulton, R., Whitney, J., Fuller, C., Forester, R.M., 
2007. Dust emission from wet and dry playas in the Mojave Desert, USA. Earth Surf. Process. Landf., 32, 1811-1827.

Rosenan, N., Gilad, M., 1985. Atlas of Israel. Meteorological data, Carta, Jerusalem.

Roskin, J., Porat, N., Tsoar, H., Blumberg, D., Zander, A.M., 2011. Age, origin and climatic controls on vegetated linear dunes in the northwestern Negev Desert (Israel). Quarter. Sci. Rev., 30, 1649-1674.

Sanchez, C., Wood, M.K., 1987. The relationship of soil surface roughness with hydrologic variables on natural and reclaimed rangeland in New Mexico. J. Hydrol., 94, 345354.

Schild, R., Wendorf, F., 2001. Geoarchaeology of the Holocene Climatic Optimum at Nabta Playa, Southwestern Desert, Egypt. Geoarchaeology, 16, 7-28.

Strauss, S.L., Day, T.A., Garcia-Pichel, F., 2012. Nitrogen cycling in desert biological soil crusts across biogeographic regions in the Southwestern United States. Biogeochemistry, 108, 171-182.

Sweeney, M.R., McDonald, E.V., Etyemezian, V., 2011. Quantifying dust emissions from desert landforms, eastern Mojave Desert, USA. Geomorphology, 135, 21-34.

Vengosh, A., Chivas, A.R., Starinsky, A., Kolodny, Y., Zhang, B., Zhang, P., 1995. Chemical and boron isotope compositions of non-marine brines from the Qaidam Basin, Qinghai, China. Chem. Geol., 120, 135-154.
Ward, J.D., 1988. Eolian, fluvial and pan (playa) facies of the Tertiary Tsondab Sandstone Formation in the central Namib Desert, Namibia. Sedimen. Geol., 55, 143-162.

Weltzin, J.E., Bridgham, S.D., Pastor, J., Chen, J., Harth, C., 2003. Potential effect of warming and drying on peatland plant community composition. Global Change Biol., 9, $141-151$.

Wetzel, R.G., Westlake, D.F., 1969. Periphyton. In: Vollenweider, R.A. (Ed.): A Manual on Methods for Measuring Primary Production in Aquatic Environments. Blackwell Scientific, Oxford (UK), pp. 33-40.

Wondzell, S.M., Cornelius, J.M., Cunningham, G.L, 1990. Vegetation patterns, microtopography, and soils on a Chihuahuan desert playa. J. Veg. Sci., 1, 403-440.

Yang, H., Wu, M., Liu, W., Zhang, Z., Zhang, N., Wan, S., 2011. Community structure and composition in response to climate change in a temperate steppe. Global Change Biol., $17,452-465$.

Yoder, R.E., Johnson, D.L., Wilkerson, J.B., Yoder, D.C., 1998. Soil water sensor performance. Appl. Eng. Agric. 14, 121-133.

Yu, J., Grishkan, I., Sherman, C., Steinberger, Y., 2012. Spatiotemporal variability of cultivable microfungal communities inhabiting a playa area in the western Negev Desert, Israel. J. Arid Environ., 81, 9-17.

Received 24 July 2015 Accepted 5 November 2015 